Not far

behind are

proteins to

treat the nerve

damage

associated

with such

neurological

conditions as

Alzheimer's,

Parkinson's, and stroke.

Table 1. 1992 venturebacked IPOs. move ILGF-1 into phase II trials soon for treatment of chemotherapyinduced peripheral neuropathy. Regeneron, meanwhile, is planning later this year to begin testing CNTF in patients with muscle-wasting disorders, such as spinal muscular dystrophy and Bell's Palsy.

These disorders are ideal first targets for the young field of neuropharmaceutical research, because they involve nerve cells outside of the brain, and therefore the neuropharmaceuticals do not have to cross the largely impermeable blood-brain barrier. Currently, delivery of pharmaceuticals to the brain is done through off-the-shelf implantable pumps, but this is merely a stop-gap technology designed to get drugs into clinical trials.

Alkermes (Cambridge, MA) is tackling this delivery problem by linking brain neuroproteins with an antibody to the transferrin receptor, which covers the cells of the bloodbrain barrier. Results published in
January provide the first evidence that such an approach works in delivering across the blood-brain barrier in rats systemically injected nerve growth factor (NGF) linked to transferrin-receptor antibodies. For their parts, Somatix Therapy (Alameda, CA) and Cytotherapeutics (Providence, RI) are developing implantable, genetically engineered cells - encapsulated within semi-permeable membranes to prevent tissue rejection - that would produce protein-based drugs directly within the brain.

\section{Brain barrier}

Should such delivery efforts succeed, neuropharmaceutical firms could have a host of drugs ready to take advantage of the new technologies. A number of companies are eager to test NGF as a treatment for Alzheimer's disease, because it protects the very cells damaged in this condition, the cholenergic nerve cells in the basal forebrain. Synergen recently discovered a brain protein, called Parkinson's factor, that stimulates growth of the cells damaged in Parkinson's disease, the dopaminergic nerve cells in the substantia nigra. Synergen is also studying basic fibroblast growth factor (bFGF) as a therapeutic for stroke damage, as it believes that bFGF protects brain nerve cells from destruction caused by loss of blood flow. Moreover, Regeneron and Amgen (Thousand Oaks, CA) have formed a partnership to develop several neuroproteins, including brain-derived neurotrophic factor, neurotrophin-3, and neurotrophin-4.

Cephalon is taking a different approach to the blood-brain-barrier problem by developing small molecules that slip through the barrier and bind to the nerve-cell receptors for the natural neuroproteins. Working with Kyowa Hakko Kogyo (Tokyo), Cephalon is currently testing one such molecule, CEP-075, for treating stroke and head trauma. Clinical trials are scheduled to start later this year. -Joseph Alper

\title{
Biotech boosts 1992 venture-backed IP0 market
}

NEW YORK - Last year was a record year for U.S. venture-capital-backed initial public offerings (IPOs), as 151 venture-backed companies tapped the public market for $\$ 4.4$ billion (Table 1), reports Venture Economics Publishing (Newark, NJ). This topped the previousrecord performance of 1991, when 121 venture-backed IPOs netted $\$ 3.8$ billion.

Biotechnology played a big role in last year's venture-backed IPO market. Fully 24 venture-backed biotech companies went public last year, accounting for 16 percent of the year's venture-backed IPOs. Indeed, the biotech sector was second only to the medical/health-related sector, whose 38 venturebacked IPOs made up 25 percent of such 1992 offerings.

The 24 biotech IPOs raised an average of $\$ 27.5$ million each last year, 6 percent less than the $\$ 29.3$ million raised by all of last year's venture-backed IPOs, on average. The 19 consumer-related IPOs led the way in 1992, taking home an average of $\$ 40$ million apiece.

Last year's 24 biotech IPOs had an average offering price of $\$ 10.09$ a share. This was 9 percent less than the $\$ 11.03$ offering price averaged by all of the venture-backed IPOs in 1992. Not surprisingly, the 19 consumer-related IPOs were the leaders, with an offering price of $\$ 13.79$, on average.

The 24 biotech IPOs performed poorly in the aftermarket, with an average stock price increase of just 1 percent by the year's end. In contrast, all of last year's venturebacked IPOs rose an average of 25 percent by the end of the year. The computer-software-and-services IPOs showed the biggest gain, soaring 51 percent, on average. In fact, four biotech firms were among the 10 worstperforming venturebacked IPOs in 1992. They included Cellcor (Newton, MA), with a 77 percent stock-price drop; Protein Polymer Technologies (San Diego, CA), with a 65 percent fall; Sphinx Pharmaceuticals (Durham, $\mathrm{NC}$ ), with a 53 percent drop; and AgriDyne Technologies (Salt Lake City, UT), with a 50 percent fall. -B.J. Spalding 